\title{
Effect of obesity on risk and severity of periodontitis: a cross-
}

\section{sectional study [version 1; peer review: 1 approved, 1}

\section{approved with reservations]}

\author{
Chaerita Maulani(iD1, Elza Ibrahim Auerkari (iD2, Sri Lelyati C. Masulili³, \\ Lindawati S. Kusdhany ${ }^{4}$, Chiquita Prahasanti ${ }^{5}$, Nurtami Soedarsono ${ }^{2}$ \\ ${ }^{1}$ Doctoral Program, Faculty of Dentistry, Universitas Indonesia, Jakarta, 10430, Indonesia \\ ${ }^{2}$ Department of Oral Biology, Faculty of Dentistry, Universitas Indonesia, Jakarta, 10430, Indonesia \\ ${ }^{3}$ Department of Periodontology, Faculty of Dentistry, Universitas Indonesia, Jakarta, 10430, Indonesia \\ ${ }^{4}$ Departement of Prosthodontics, Faculty of Dentistry, Universitas Indonesia, Jakarta, 10430, Indonesia \\ ${ }^{5}$ Departement of Periodontology, Faculty of Dentistry, Universitas Airlangga, Surabaya, 60132, Indonesia
}

V1 First published: $23 \mathrm{Jul} 2021, \mathbf{1 0 : 6 4 3}$

https://doi.org/10.12688/f1000research.53823.1

Latest published: 25 Jan 2022, 10:643

https://doi.org/10.12688/f1000research.53823.2

\section{Abstract}

Background: The present study aimed to investigate

the correlation between obesity and periodontitis, among other risk

factors for periodontitis.

Methods: In total, 262 Indonesian male and female subjects were analysed for body mass index (BMI), oral hygiene, plaque index, and clinically evaluated periodontitis. Statistical analysis was performed using Spearman tests and Pearson chi-square tests to estimate the correlation between BMI and periodontitis. Multivariate binary logistic analysis was conducted between covariate and

periodontitis. $\mathrm{P}<0.05$ was considered as statistically significant.

Results: The prevalence of obesity was $48.47 \%$. There were positive correlations between BMI and periodontal status for healthymild periodontitis, moderate, and severe periodontitis respectively. $\mathrm{BMI}$ and periodontitis crude odds ratio $(\mathrm{OR})=2.31$ (95\% CI 1.41-

3.78); $p<0.05$, adjusted OR of BMI among other

variables, was 1.88 (95\%CI 1.05-3.37); $p<0.05$. Exploration of the ROC curve found a BMI cut off point of $24.785 \mathrm{~kg} / \mathrm{m} 2$.

Conclusion: Obesity by BMI measurement of $\geq 25 \mathrm{~kg} / \mathrm{m} 2$ correlated to a higher risk of acquiring periodontitis compared to normal-weight individuals.

\section{Keywords}

Body mass index, obesity, periodontitis

\section{Open Peer Review}

Approval Status

1

2

version 2

(revision)

$25 \operatorname{Jan} 2022$

version 1

23 Jul 2021

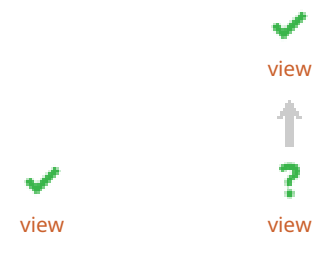

1. Euis Reni Yuslianti (D), Jenderal Achmad

Yani University, Cimahi, Indonesia

2. Muhammad Sohail Zafar (D), Taibah

University, Medina, Saudi Arabia

Any reports and responses or comments on the article can be found at the end of the article. 
Corresponding author: Elza Ibrahim Auerkari (elza.ibrahim@ui.ac.id)

Author roles: Maulani C: Data Curation, Investigation, Visualization, Writing - Original Draft Preparation, Writing - Review \& Editing; Auerkari EI: Conceptualization, Resources, Supervision, Validation, Writing - Review \& Editing; C. Masulili SL: Methodology, Resources, Supervision; Kusdhany LS: Formal Analysis, Supervision, Validation; Prahasanti C: Formal Analysis, Supervision; Soedarsono N: Data Curation, Formal Analysis

Competing interests: No competing interests were disclosed.

Grant information: This research was funded by Universitas Indonesia grant number BA1072/UN2.RST/PPM.00.03.01/2020 to EIA. The funders had no role in study design, data collection and analysis, decision to publish, or preparation of the manuscript. The funders had no role in study design, data collection and analysis, decision to publish, or preparation of the manuscript.

Copyright: (c) 2021 Maulani C et al. This is an open access article distributed under the terms of the Creative Commons Attribution License, which permits unrestricted use, distribution, and reproduction in any medium, provided the original work is properly cited.

How to cite this article: Maulani C, Auerkari EI, C. Masulili SL et al. Effect of obesity on risk and severity of periodontitis: a crosssectional study [version 1; peer review: 1 approved, 1 approved with reservations] F1000Research 2021, 10:643

https://doi.org/10.12688/f1000research.53823.1

First published: 23 Jul 2021, 10:643 https://doi.org/10.12688/f1000research.53823.1 


\author{
Abbreviations \\ AUC: Area under curve \\ BMI: Body mass index \\ BOP: Bleeding on probing \\ CAL: Clinical attachment loss \\ $\mathrm{CI}$ : Confidence of interval \\ COPD: Chronic obstructive pulmonary disease \\ IQR: Interquartile range \\ OHI: Oral hygiene index \\ OR: Odds ratio \\ PD: Pocket Depth \\ PI: Plaque index \\ ROC: Receiver operating characteristic
}

\title{
Introduction
}

Chronic periodontitis shares many common risk factors with other chronic diseases such as hypertension, cardiovascular disease, and type 2 diabetes mellitus. Common risk factors include smoking, alcohol consumption, and obesity. The underlying mechanisms related to obesity are thought to contribute to inflammation and thereby to chronic disease. ${ }^{1}$

The etiology of chronic periodontitis derives from the series of complex interactions between pathologic microorganisms in the bacterial plaque and the host and modifications by systemic and local factors. ${ }^{2}$ Susceptibility to periodontitis also affected by genetic factors which modulate individual responses to the environment and variations of the immune response. $^{3}$ There are many proinflammatory cytokines involved in periodontitis subjects, such as IL-1, IL-6, TNF- $\alpha$ which also correlates with proinflammatory cytokines in obese patients ${ }^{4}$ (Makki, 2013). Obesity modulates the host immune response by secreting several proinflammatory factors deriving from adipose tissue (adipocytes) which results in increased bone loss.

Obesity has become a worldwide concern because it's incidence has nearly tripled since 1975. In 2016 more than 1.9 billion adults 18 years and older were overweight, with 650 millions of those being obese. ${ }^{6}$ The prevalence of obesity among adults over 18 years old in the U.S. was $39.8 \%$ according to a National Health and Nutrition Examination Survey conducted in 2015-2016. Asian non-Hispanic adults had the lowest prevalence (12.7\%) compare with all other races and Hispanic-origin groups. ${ }^{7}$

In Indonesia according to Indonesian basic health research 2018 (Riskesdas, 2018) the prevalence of obesity in Indonesian adults over 18 years old was $21.8 \%$ and the prevalence of periodontitis was $74.1 \%$. Jakarta, the Indonesian capital city, has the second highest obesity prevalence among 34 other provinces at $29,8 \%$ whilst the prevalence of periodontitis in urban areas was $71.5 \%{ }^{8}$

Obesity is usually defined by body mass index (BMI) measurement. According to the WHO, 'overweight' classification is set at the value of $25.0-29.9 \mathrm{~kg} / \mathrm{m}^{2}$ and 'obesity' defined as a BMI $\geq 30.0 \mathrm{~kg} / \mathrm{m}^{2}$. However in Asian regions BMIs can be set lower than the existing WHO cut-off point, with the overweight BMI at $22-25 \mathrm{~kg} / \mathrm{m}^{2}$ and the obesity BMI at $26-31 \mathrm{~kg} / \mathrm{m}^{2}$. ${ }^{9}$ The WHO proposed classification of a weight by BMI in adult Asians for which obesity 1 is defined at $25-29.9 \mathrm{~kg} / \mathrm{m}^{2}$ and obesity 2 at $\geq 30 \mathrm{~kg} / \mathrm{m}^{2}$.

Increased BMI may be a potential risk factor for developing periodontitis. ${ }^{11-13}$ On the other hand, other studies have shown obesity to be not related to the severity of periodontal disease, ${ }^{14}$ but associated with tooth loss, oral hygiene and education level. ${ }^{15}$ Obesity is related to adipokines that are secreted from adipose tissue which has an important role in regulating metabolic and vascular biology. ${ }^{16}$ Meanwhile, as a result of chronic inflammatory state insulin resistance develops as well as oxidative stress. These factors could be implicated in the possible obesity and periodontitis association. ${ }^{17} \mathrm{BMI}$ and obesity in non-surgical periodontal therapy also appear to be independent predictors of poor response to the treatment. ${ }^{18}$

The aim of this study was to ascertain the odds of having periodontitis in obese individuals among other periodontitis risk factors. We hypothesized that obesity correlated with having higher risk of periodontitis compared to normal-weight individuals. 


\section{Methods}

Study design and participants

This cross-sectional study was conducted three subdistrict populations in Central Jakarta from July 2018 to March 2019. The subjects were recruited by consecutive sampling. The inclusion criteria were: healthy male and female participants aged 18-66 years old, having at least 14 teeth, who were willing to participate in the study and sign an informed consent. Exclusion criteria were any disease that could affect the general and oral health of the subject.

\section{Ethical approval}

Official permission was obtained from the corresponding authorities in DKI Jakarta which give legal permission to do the study in Central Jakarta subdistrict and ethical approval was obtained from the Dental Research Ethics Committee of the Faculty of Dentistry, Universitas Indonesia with the protocol number 070390418, and ethical approval number 38/Ethical Approval/FKGUI/V/2018.

\section{Data collection}

Subject height was measured in centimetres and weight was assessed by a calibrated mechanical scale in kilograms. BMI was calculated by ratio weight and height squared (BMI calculated as $\mathrm{kg} / \mathrm{m}^{2}$ during data processing). Four categories of BMI defined by the WHO in accordance with the Asia-Pacific perspective were BMI $<18.5 \mathrm{~kg} / \mathrm{m}^{2}$ as underweight, BMI 18-5-22.9 as normal weight, BMI 23.0-24.9 as overweight, BMI 25.0-29.9 as obesity 1, and $\geq 30 \mathrm{~kg} / \mathrm{m}^{2}$ as obesity $2 .^{10}$

Periodontal examination was performed using periodontal probe UNC-15. Clinical parameters of oral hygiene were measured by the simplified oral hygiene index $(\mathrm{OHI})^{19}$ and plaque index (PI). ${ }^{20}$ Periodontal status was recorded by pocket depth (PD), recession, and clinical attachment loss (CAL) which measured six sites per tooth except for third molars. Measurements were made in millimetres and were rounded to the nearest whole millimetre. Bleeding on probing was recorded with papilla bleeding index (PBI) by Saxer and Muhlemann ${ }^{21}$ and the number of teeth also recorded.

Patients were also categorized according to periodontal condition where CAL $5 \mathrm{~mm}$ and PD $6 \mathrm{~mm}$ were cut off measurements between mild and severe periodontitis. ${ }^{22}$ Severe periodontitis was determined as CAL $\geq 5 \mathrm{~mm}$ at more than 18 sites and $\mathrm{PD} \geq 6 \mathrm{~mm}$ in at least one site. Moderate periodontitis determined as CAL $\geq 5 \mathrm{~mm}$ at 9-18 sites and $\mathrm{PD} \geq 6 \mathrm{~mm}$ at not more than one site. Mild periodontal status (healthy gingiva, gingivitis and mild periodontitis) was determined by CAL $\geq 5 \mathrm{~mm}$ at not more than eight sites and no PD $\geq 6 \mathrm{~mm}$. The periodontal measurement was taken by calibrated periodontists. Analysis of inter-examiner reliability for periodontal status and plaque index was performed, and demonstrated good agreement.

\section{Statistical analysis}

The Statistical Package for the Social Sciences (SPSS version 23.0) was used to process data. If there were missing data, the samples were excluded from the study. The normality test and descriptive statistics were calculated using Shapiro-Wilk or Kolmogorov-Smirnov tests for distribution with BMI as the dependent factor. Normally distributed data were presented as mean and standard deviation, non-normally distributed data presented as medians and interquartile range (IQR), and categorical data as percentages. We analyzed the correlation between confounding factors and periodontal status with BMI in continuous data. The confounding factors and periodontitis in dichotomy was correlated with five categorical BMI. The correlation between continuous data of clinical parameter periodontal and categorical BMI was assessed. The association between healthy and mild periodontitis, moderate periodontitis, periodontitis and BMI were calculated using Kruskal Wallis tests. Dichotomy of periodontal statuses as dependent variables determined the correlation with periodontitis risk-factors including BMI. The confounding factors were controlled by multiple logistic regression. Both significant crude odds ratio and adjusted ratio were calculated to assess influenced independent variables on periodontal status $(95 \% \mathrm{CI})$. The effect of each independent variable was measured adjusting for all variables in the model; $\mathrm{p}<0.05$ was accepted as statistically significant. The ROC was also measured to seek the specific BMI cutoff point in periodontitis (binary) within this study. We included all the subject that match the inclusion criteria until minimal number sample were sufficient.

\section{Results}

A total of 272 subjects were recruited; however, some subjects were not eligible according to the inclusion criteria: such as having fewer than 14 teeth, or age. Missing data were excluded (Figure 1). Therefore, a total of 262 subjects between the ages of 18 and 66 were included in this study. The percentage of female subjects was larger (59.9\%) than male subjects (40.1\%) as presented in the general profile (Table 1). The age group of 45-54 made up two fifths of the sample size, whereas the fewest subjects were in the 25-34 years age group. Subject's education status was mostly high school (53.4\%) and the primary occupation was housewife (47.3\%). The subjects were mostly non-smokers (79.4\%) and 
Selection of patients (July 2018-March 2019)

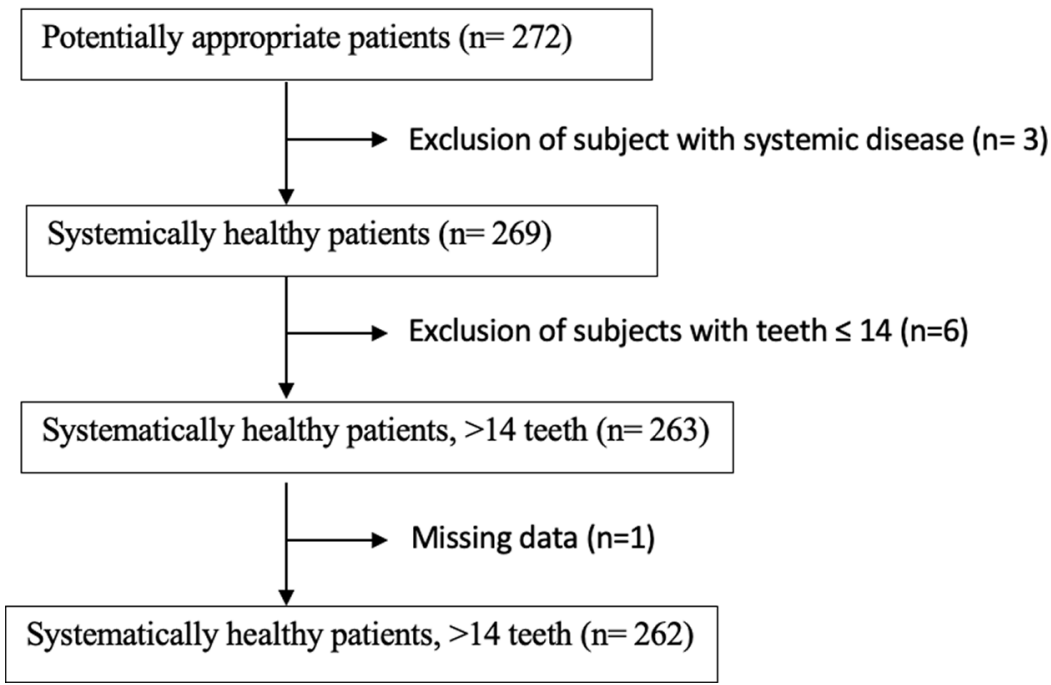

Figure 1. Flow diagram of the study.

non-alcohol-consumers (93.5\%). 50.8\% of subjects had either healthy periodontal scores or mild periodontitis, and the rest had moderate or severe periodontitis.

The socio-demographic and BMI analysis showed significant positive correlations for age, sex, hypertension, and periodontal status. Significant negative correlations were shown for occupation and smoking status (coefficient correlation $-0.270, \mathrm{p}=0.000$; coefficient correlation $-0.142, \mathrm{p}=0.021$, respectively) (Table 1). Education, alcohol, $\mathrm{DM}$, and plaque index showed no correlations with periodontal status.

The prevalence of obesity in this study was $48.47 \%$ and the highest prevalence was in BMI group $25.0-29.9 \mathrm{~kg} / \mathrm{m}^{2}$ $(32.44 \%)$, then $18.5-22.9 \mathrm{~kg} / \mathrm{m}^{2}(29.77 \%)$. Table 2 presents the correlation between binary socio-demography data, oral hygiene, and BMI as a dependent factor. A significant positive correlation found between periodontitis and age, sex, occupation, and hypertension and while smoking showed a negative correlation. Continuous data of the clinical parameters of periodontitis and BMI is shown in Table 3. PD, CAL, and PBI were found to have significant correlations with BMI.

A significant positive correlation found between BMI and periodontal status. There was and association between mild periodontal status and moderate periodontitis, and between mild periodontal status and severe periodontitis were $\mathrm{p}=0.03$ and $\mathrm{p}=0.04$ respectively (Figure 2 ).

Binary periodontal status categorized moderate and severe periodontitis as one group and healthy periodontal and mild periodontitis as another group. Binary periodontal status was then analyzed as a dependent factor towards the various risk factors (Table 4). The multivariate logistic regression analysis was then performed for variables with $\mathrm{p}<0.25$ (age, sex, smoking, DM, BMI and OHIS). Diabetes mellitus status and smoking had $p$-values above 0.25, which were $p=0.301$ and $\mathrm{p}=0.431$ respectively, but both were included in the analyses because DM and smoking status are both important risk factors in periodontal classification.

Multivariate logistic regression analysis showed that periodontitis subjects were more likely to have a BMI $\geq 25 \mathrm{~kg} / \mathrm{m}^{2}$ ( $\mathrm{p}<0.001$; adjusted odds ratio $1.881 ; 95 \%$ CI: 1.050-3.371). The risk of periodontitis was higher in male compare to female ( $\mathrm{p}<0.001$; adjusted OR 6.852; 95\%CI: 2.540-18.481), and increased with OHI. Adjusted OR for smoking showed that nonsmoking subjects were more prone to periodontitis. The ROC analyses from multivariate logistic regression had an area under the curve of 0.78 (sensitivity $71.3 \%$, specificity $61.7 \%$ ), determining that it was acceptable using this approach to discriminate between those individuals with healthy or mild periodontitis and severe periodontitis.

Despite the fixed value of the Asian cut-off point in BMI, we tried to estimate the cut-off point of BMI in our subjects. Figure 3 shows that the BMI special cut point with the periodontal status, was found in the value of $24.785 \mathrm{~kg} / \mathrm{m}^{2}$ (sensitivity $60.5 \%$, specificity $60.9 \%$, AUC 0.608). 


\begin{tabular}{|c|c|c|c|c|c|}
\hline Characteristic & $\mathbf{n}$ & (\%) & BMI $\left(\mathrm{kg} / \mathrm{m}^{2}\right)$ & $\begin{array}{l}\text { Correlation } \\
\text { coefficient }\end{array}$ & P-value \\
\hline Age (years), median (IQR) & & & & & 0.000 \\
\hline $18-24$ & 49 & 18.7 & $21.83(5.16)$ & $0.286^{\mathrm{a} * *}$ & \\
\hline $25-34$ & 28 & 10.7 & $22.61(5.43)$ & & \\
\hline $35-44$ & 30 & 11.5 & $26.40(7.48)$ & & \\
\hline $45-54$ & 106 & 40.5 & $25.97(6.93)$ & & \\
\hline $55-66$ & 49 & 18.7 & $26.41(5.71)$ & & \\
\hline Sex, mean \pm SD & & & & $0.263^{\mathrm{b} * *}$ & 0.000 \\
\hline Male & 105 & 40.1 & $23.03(6.31)$ & & \\
\hline Female & 157 & 59.9 & $26.12(6.75)$ & & \\
\hline Education, median (IQR) & & & & $0.103^{a}$ & 0.095 \\
\hline Graduate/above & 38 & 14.5 & $24.08(5.98)$ & & \\
\hline High school & 140 & 53.4 & $24.23(6.85)$ & & \\
\hline Primary/secondary/no education & 84 & 32.1 & $25.45(5.74)$ & & \\
\hline Occupation, median (IQR) & & & & $-0.270^{a \star \star}$ & 0.000 \\
\hline Government/private/self employed & 39 & 14.9 & $25.16(6.53)$ & & \\
\hline Housewife & 124 & 47.3 & $26.41(6.59)$ & & \\
\hline College student & 19 & 7.3 & $23.84(8.41)$ & & \\
\hline $\begin{array}{l}\text { Cleaning service/security/driver/ } \\
\text { labourer }\end{array}$ & 80 & 30.5 & $22.61(5.88)$ & & \\
\hline Smoking status, median (IQR) & & & & $-0.142^{a *}$ & 0.021 \\
\hline Non-smoker & 208 & 79.4 & $25.24(6.49)$ & & \\
\hline Smoker & 54 & 20.6 & $23.01(6.43)$ & & \\
\hline Alcohol consumption, median (IQR) & & & & $-0.017^{a}$ & 0.785 \\
\hline No alcohol consumption & 245 & 93.5 & $24.77(6.24)$ & & \\
\hline Yes & 17 & 6.5 & $24.31(5.50)$ & & \\
\hline Hypertension, mean \pm SD & & & & $0.251^{\mathrm{b} * *}$ & 0.000 \\
\hline No & 188 & 71.8 & $24.54 \pm 4.76$ & & \\
\hline Yes & 74 & 28.2 & $27.34 \pm 5.17$ & & \\
\hline Diabetes Mellitus, median (IQR) & & & & $-0.021^{a}$ & 0.738 \\
\hline No & 258 & 98.5 & $24.69(6.38)$ & & \\
\hline Yes & 4 & 1.5 & $24.64(3.98)$ & & \\
\hline Plaque Index, mean \pm SD & & & & $0.082^{b}$ & 0.186 \\
\hline Slight & 130 & 49.6 & $24.91 \pm 5.07$ & & \\
\hline Abundance & 132 & 50.4 & $25.74 \pm 4.98$ & & \\
\hline Periodontal status, median (IQR) & & & & $0.208^{\mathrm{a} * *}$ & 0.001 \\
\hline Health and Mild periodontitis & 133 & 50.8 & $23.31(6.27)$ & & \\
\hline Moderate periodontitis & 54 & 20.6 & $26.17(6.03)$ & & \\
\hline Severe periodontitis & 75 & 28.6 & $26.00(6.20)$ & & \\
\hline
\end{tabular}


Table 2. Correlation between socio-demographic data, DM, hypertension, oral hygiene and body mass index.

\begin{tabular}{|c|c|c|c|c|c|c|c|}
\hline \multirow[t]{3}{*}{ Variables } & \multicolumn{5}{|c|}{ Body mass index $n(\%)$} & \multirow{3}{*}{$\begin{array}{l}\text { Coefficient } \\
\text { correlation }\end{array}$} & \multirow[t]{3}{*}{ p-value } \\
\hline & \multirow{2}{*}{$\begin{array}{l}<18.5 \\
(n=18)\end{array}$} & \multirow{2}{*}{$\begin{array}{l}18.5-22.9 \\
(n=78)\end{array}$} & \multirow{2}{*}{$\begin{array}{l}23.0-24.9 \\
(n=39)\end{array}$} & \multirow{2}{*}{$\begin{array}{l}25.0-29.9 \\
(n=85)\end{array}$} & \multirow{2}{*}{$\begin{array}{l}\geq 30.0 \\
(n=42)\end{array}$} & & \\
\hline & & & & & & & \\
\hline Age & & & & & & $0.343^{* *}$ & 0.000 \\
\hline$<30$ years & $10(15.4)$ & $30(46.2)$ & $10(15.4)$ & $14(21.5)$ & $1(1.5)$ & & \\
\hline$\geq 30$ years & $8(4.1)$ & $48(24.4)$ & $29(14.7)$ & $71(36.0)$ & $41(20.8)$ & & \\
\hline Sex & & & & & & $0.267 * \star$ & 0.000 \\
\hline Male & $12(11.4)$ & $40(38.1)$ & $16(15.2)$ & $30(28.6)$ & $7(6.7)$ & & \\
\hline Female & $6(3.8)$ & $38(24.2)$ & $23(14.6)$ & $55(35.0)$ & $35(22.3)$ & & \\
\hline Education & & & & & & 0.053 & 0.397 \\
\hline$>12$ years & $4(10.3)$ & $13(33.3)$ & $4(10.3)$ & $13(33.3)$ & $5(12.8)$ & & \\
\hline$\leq 12$ years & $14(6.3)$ & $65(29.1)$ & 35 (15.7) & $72(32.3)$ & $37(16.6)$ & & \\
\hline Occupation & & & & & & $0.188^{* *}$ & 0.002 \\
\hline Working & $10(8.5)$ & $44(37.3)$ & $18(15.3)$ & $33(28.0)$ & $13(11.0)$ & & \\
\hline Not working & $8(5.6)$ & $34(23.6)$ & $21(14.6)$ & $52(36.1)$ & $29(20.1)$ & & \\
\hline Smoking & & & & & & $-0.130 *$ & 0.036 \\
\hline Nonuser & $15(7.2)$ & $54(26.0)$ & $32(15.4)$ & $70(33.7)$ & $37(17.8)$ & & \\
\hline User & $3(5.6)$ & $24(44.4)$ & $7(13.0)$ & $15(27.8)$ & $5(9.3)$ & & \\
\hline Alcohol & & & & & & -0.131 & 0.618 \\
\hline Nonuser & $16(6.5)$ & $73(29.8)$ & $37(15.1)$ & $79(32.2)$ & $40(16.3)$ & & \\
\hline User & $2(11.8)$ & $5(29.4)$ & $2(11.8)$ & $6(35.3)$ & $2(11.8)$ & & \\
\hline Hypertension & & & & & & $0.196 * *$ & 0.001 \\
\hline No & $18(9.6)$ & $65(31.0)$ & $33(15.7)$ & $68(32.4)$ & $26(12.4)$ & & \\
\hline Yes & $0(0)$ & $13(25.0)$ & $6(11.5)$ & $17(32.7)$ & $16(30.8)$ & & \\
\hline DM & & & & & & 0.001 & 0.981 \\
\hline No & $18(7.0)$ & 77 (29.8) & 38 (14.7) & $83(32.2)$ & $42(16.3)$ & & \\
\hline Yes & $0(0.0)$ & $1(25.5)$ & $1(25.0)$ & $2(50.0)$ & $0(.0)$ & & \\
\hline Periodontitis & & & & & & $0.219 * \star$ & 0.000 \\
\hline Mild & $16(12.0)$ & $44(33.1)$ & $22(16.5)$ & $34(25.6)$ & $17(12.8)$ & & \\
\hline Severe & $2(1.6)$ & $34(26.4)$ & $17(13.2)$ & $51(39.5)$ & $25(19.4)$ & & \\
\hline $\mathrm{OHI}$ & & & & & & -0.027 & 0.664 \\
\hline Good (0.0-2.00) & $8(6.1)$ & $41(31.1)$ & $18(13.6)$ & 41 (31.1) & $24(18.2)$ & & \\
\hline Poor (2.01-6.00) & $10(7.7)$ & $37(28.5)$ & $21(16.2)$ & $44(33.8)$ & $18(13.8)$ & & \\
\hline Plaque Index & & & & & & 0.095 & 0.124 \\
\hline Slight (0.0-1.39) & $10(7.7)$ & 45 (34.6) & $16(12.3)$ & $41(31.5)$ & $18(13.8)$ & & \\
\hline Abundance (1.4-3.0) & $8(6.1)$ & $33(25.0)$ & $23(17.4)$ & $44(33.3)$ & $24(18.2)$ & & \\
\hline
\end{tabular}

Spearman test.

\section{Discussion}

A previous study (in which the age ranged from 25 to 66 years) showed that the prevalence of periodontitis was greater among subjects with obesity and the increased was BMI proposed as potential risk factor for periodontitis. ${ }^{12}$ Sources of potential bias were that BMI and not body fat distribution, which can be calculated by waist circumference (WC), was measured. Fat distribution varies between woman and men and between race/ethnic groups. ${ }^{23,24}$ Participants were taken from three district in central Jakarta which represent mixed ethnic in Indonesia and can be generalized as Indonesian sub population. 
Table 3. Correlation of clinical parameter periodontitis and BMI.

\begin{tabular}{|c|c|c|c|c|c|c|c|}
\hline \multirow{3}{*}{$\begin{array}{l}\text { Variables, } \\
\text { Median (IQR) }\end{array}$} & \multicolumn{5}{|c|}{ Body mass index } & \multirow{3}{*}{$\begin{array}{l}\text { Correlation } \\
\text { coefficient }\end{array}$} & \multirow[t]{3}{*}{ p-value } \\
\hline & \multirow{2}{*}{$\begin{array}{l}<18.5 \\
(n=18)\end{array}$} & \multirow{2}{*}{$\begin{array}{l}18.5-22.9 \\
(n=78)\end{array}$} & \multirow{2}{*}{$\begin{array}{l}23.0-24.9 \\
(n=39)\end{array}$} & \multirow{2}{*}{$\begin{array}{l}25.0-29.9 \\
(n=85)\end{array}$} & \multirow{2}{*}{$\begin{array}{l}\geq 30.0 \\
(n=42)\end{array}$} & & \\
\hline & & & & & & & \\
\hline $\mathrm{PD}^{\mathrm{a}}(\mathrm{mm})$ & $1.49(0.48)$ & $1.64(0.50)$ & $1.67(0.59)$ & $1.80(0.60)$ & $1.74(0.66)$ & 0.206 & 0.001 \\
\hline $\mathrm{CAL}^{\mathrm{a}}(\mathrm{mm})$ & $1.85(0.65)$ & $2.04(1.26)$ & $2.33(1.24)$ & $2.47(1.02)$ & $2.31(1.00)$ & 0.217 & 0.000 \\
\hline $\mathrm{BOP}^{\mathrm{a}}$ & $0.96(0.99)$ & $1.05(1.04)$ & $0.96(1.06)$ & $1.16(1.04)$ & $1.45(1.39)$ & 0.164 & 0.008 \\
\hline $\begin{array}{l}\text { Number of } \\
\text { teeth }^{a}\end{array}$ & $25.5(4)$ & $26(5)$ & $26(6)$ & $25(5)$ & $25(5)$ & -0.11 & 0.084 \\
\hline $\begin{array}{l}\mathrm{OHI}^{\mathrm{b}} \\
(\text { mean } \pm \mathrm{SD})\end{array}$ & $2.11 \pm 0.92$ & $2.05 \pm 0.93$ & $2.19 \pm 0.85$ & $2.11 \pm 0.88$ & $1.96 \pm 0.87$ & -0.023 & 0.715 \\
\hline $\begin{array}{l}\text { Plaque index }{ }^{b} \\
(\text { mean } \pm \text { SD) }\end{array}$ & $1.12 \pm 0.45$ & $1.08 \pm 0.54$ & $1.26 \pm 0.53$ & $1.17 \pm 0.50$ & $1.14 \pm 0.49$ & 0.047 & 0.453 \\
\hline
\end{tabular}

${ }^{a}$ Spearman tests.

bearson tests.

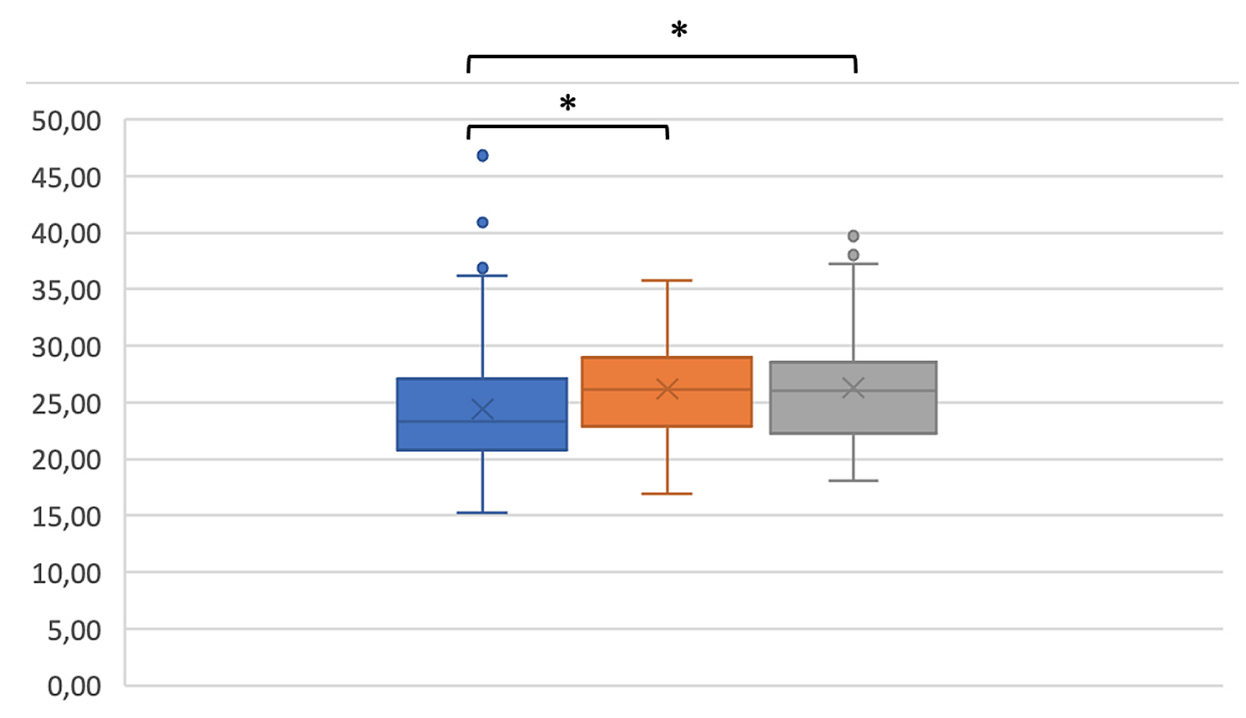

Health-Mild Periodontitis $\square$ Moderate Periodontitis $\square$ Severe Periodontitis

Figure 2. Body mass index and periodontal status; Kruskal-Wallis test * $p<0.05$.

The present study covered a slightly wider range of age from 18 up to 66 years old. The highest group with severe periodontitis was in the 45-54 years age group (46.5\%). Indonesian prevalence data for periodontitis also showed the biggest prevalence was in $45-54$ years age group $(77.85 \%){ }^{8}$

The WHO BMI categories define underweight $\left(<18.5 \mathrm{~kg} / \mathrm{m}^{2}\right)$, normal weight $\left(18.5-24.9 \mathrm{~kg} / \mathrm{m}^{2}\right)$ and overweight $\left(25.0-29.9 \mathrm{~kg} / \mathrm{m}^{2}\right)$, and obese $\left(\geq 30 \mathrm{~kg} / \mathrm{m}^{2}\right)$ while in WHO Asia-Pacific the agreed cut-off for overweight, obese I and obese II category are $23.0 \mathrm{~kg} / \mathrm{m}^{2}, 25-29.9 \mathrm{~kg} / \mathrm{m}^{2}$ and $\geq 30 \mathrm{~kg} / \mathrm{m}^{2}$ respectively. ${ }^{10}$ In the Asia-Pacific area, the BMI cut-off for obesity is $25 \mathrm{~kg} / \mathrm{m}^{2}$ rather than the WHO cut-off which is $30 \mathrm{~kg} / \mathrm{m}^{2}{ }^{25}$ We have assumed that the BMI classification for the Asia-Pacific region is more suitable for Asian patients.

The specific cut off BMI in this study of $24.785 \mathrm{~kg} / \mathrm{m}^{2}$ (sensitivity $61.1 \%$, specificity $61 \%$, AUC 0.63 ) shows resemblance to a study by Suvan et al. which has a cut-off point of $24.32 \mathrm{~kg} / \mathrm{m}^{2}$ (sensitivity $61.54 \%$, specificity $61.89 \%$ ). ${ }^{12}$ Likelihood ratio (LR) in this study was 1.56 (the disease is 1.56 times more likely in individual with the BMI $\geq 24.78$ compare to normal weight $<24.78$ ). This exploration by use of the ROC curve confirmed that using WHO Asian-Pacific standard was more suitable in our study rather than BMI $25-29.99 \mathrm{~kg} / \mathrm{m}^{2}$ defined for overweight and BMI $\geq 30 \mathrm{~kg} / \mathrm{m}^{2}$ for obesity. ${ }^{6}$ The BMI increased with increasing age and severity of periodontitis. Both the continuous data and the categorical data showed 


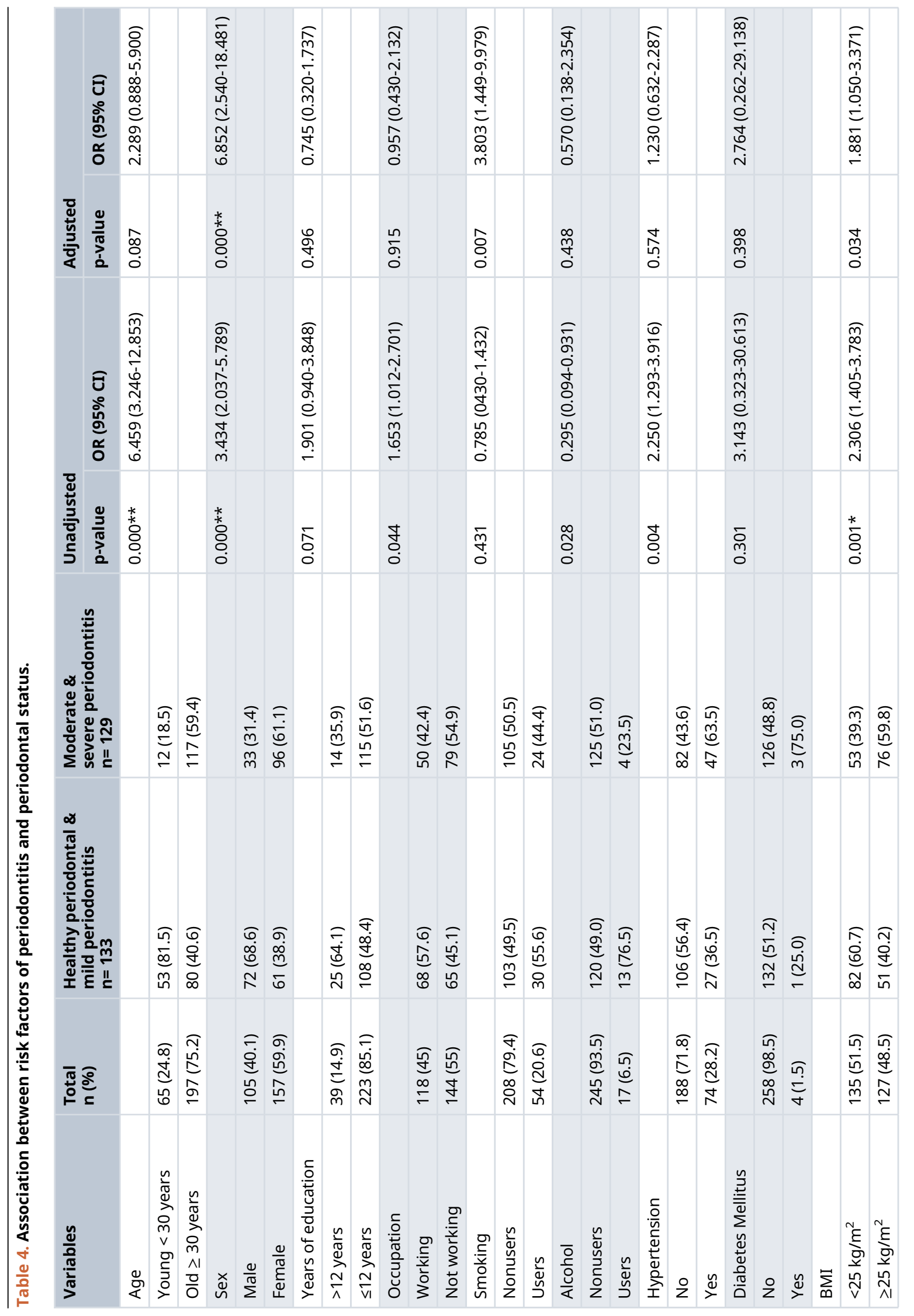




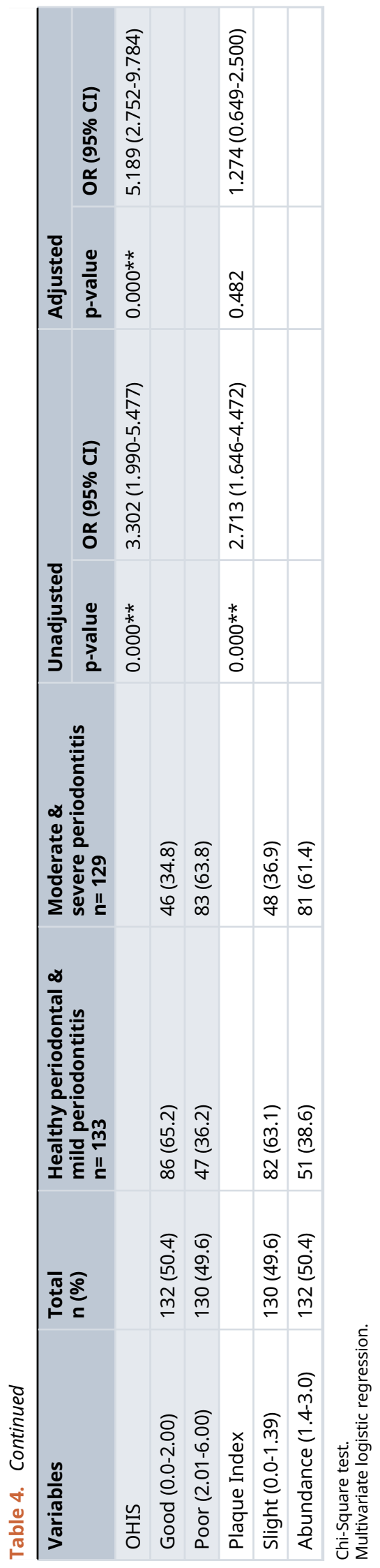




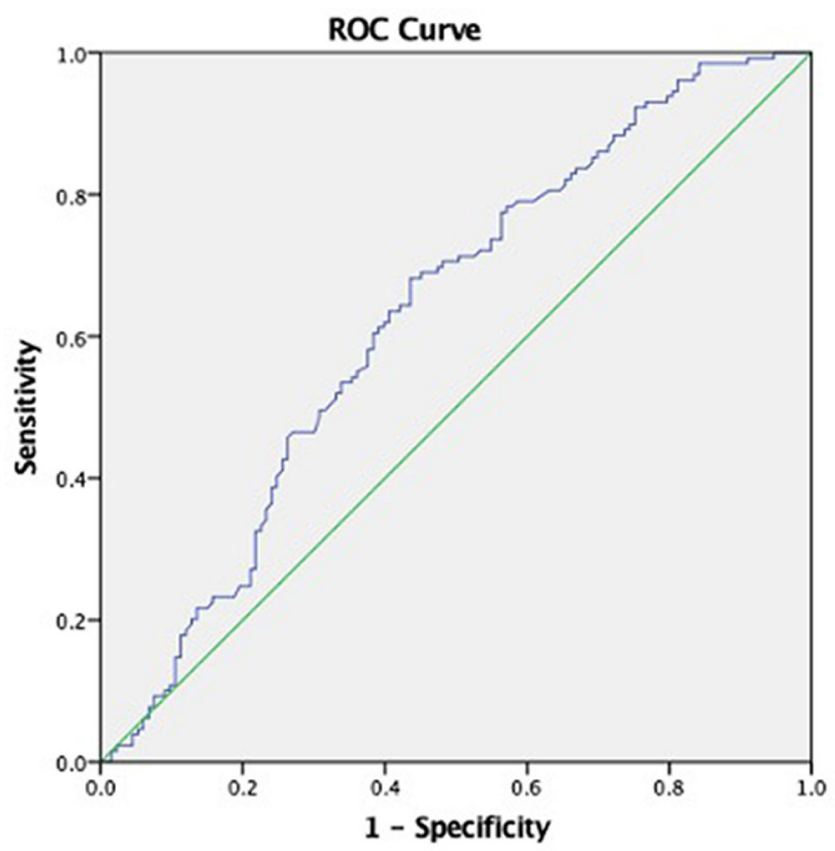

Figure 3. Cut off point body mass index: $A U C=0.629 ; \mathrm{BMI}=\mathbf{2 4 . 7 8 5} \mathrm{kg} / \mathrm{m}^{2}$; sensitivity $60.5 \%$, specificity $60.9 \%$.

correlations between BMI and periodontitis. This data was in agreement with previous studies among the population aged $28-55^{11}$ and among adults aged 18 to 24 years. ${ }^{26}$ The clinical parameters of periodontitis (PD, CAL, recession and BOP) presented positive correlations with BMI $(\mathrm{p}<0.05)$. This finding was in line with Zimmermann et al. , a German population cohort study which also found an increased deeper periodontal pocket with higher BMI $(\mathrm{OR}=1.6$, BMI increase by 5$){ }^{27}$

In this study, education level was at the margin of statistical significance ( $\mathrm{p}=0.053)$, as in a previous study which showed association with education, tooth loss, and oral hygiene. ${ }^{15}$ Tooth loss and oral hygiene were not related to increased $\mathrm{BMI}$ in this study, may be because the lowest remaining teeth was 14 teeth as an inclusion criteria while in that study, there was no particular inclusion criteria based on tooth loss. Song et al. in their study found that tooth loss was considered a potential risk indicator for being underweight in Korean adults. ${ }^{28}$ Regarding poor periodontal health with obesity, subjects had poor compliance towards oral hygiene, ${ }^{13}$ and obese patients had an approximately three fold higher number of bacterial species present compared with normal weight controls with total of 23 species. ${ }^{27}$ In this study, oral hygiene was not related to BMI although oral hygiene is significantly related with the severity of periodontitis.

Although many studies have shown the relationship between BMI and periodontitis ${ }^{17,27,29,30}$ as in this study, there are some studies which have on the contrary showed no difference between no or mild periodontitis, moderate periodontitis and severe periodontitis. ${ }^{15,31}$ Also in another study of BMI and periodontitis in postmenopausal women, those with higher BMI had decreased odds (OR) for having periodontitis compared to participants with normal weight (OR: $0.54 ; 95 \%$ CI: $0.27-0.87$ ) although the obese presented significantly higher clinical attachment loss and gingival index compared to normal and overweight subjects $(\mathrm{p}<0.01) .{ }^{32}$ On the contrary, Puspitadewi et al. in the study of postmenopausal women found no significant correlation between age, BMI, bone density and alveolar bone resorption $(\mathrm{p}>0.05){ }^{33}$

Females had a higher BMI compared to male subjects, and according to occupation housewives have the highest BMI compared to employed subjects and students, this corresponds with other studies that have found females to have a higher BMI compared to males. ${ }^{15}$ Smoking subjects in this study had a lower BMI than non-smoking subjects. Smoking was not correlated with periodontitis, but after adjusting other covariates, a significant correlation was found between nonsmokers and periodontitis. This may be due to the low percentage of smokers (20.6\%) compared to non-smokers $(79.4 \%)$ in our study. BMI has multiple risk factors (Table 2) but after multivariate logistic regression with BMI as dependent factor, only age give a significant result p < 0.001; OR 3.63 (95\% CI, 1.86-7.12).

Multivariate regression in role factors in having periodontitis, adjusted OR showed sex, OHI, smoking, and BMI, $\mathrm{p}<0.001$, OR 6.852 95\% CI; $\mathrm{p}<0.001$, OR 5.189 95\% CI 2.752-9.784; $\mathrm{p}=0.007$, OR 3.803 95\% CI 1.449-9.979; 
and $\mathrm{p}=0.034$; OR $1.88195 \%$ CI 1.050-3.371 respectively. Together, it means obese male non-smokers with bad oral hygiene are prone to periodontitis.

The odds ratio for BMI was 1.881 (95\% CI 1.050-3.371) slightly higher than a previous study where OR was 1.56 (95\% CI 1.26-1.92). ${ }^{26}$ This finding was contrary to a study in Korea by Kim et al. who with multivariate analysis found no association between BMI and periodontitis with BMI $\geq 25$, adjusted ratio 0.991 (95\% CI 0.806-1.220) but found a significant association between abdominal obesity and periodontitis with an adjusted odds ratio of 1.358 (95\% CI 1.0031.839). ${ }^{14}$ Associations between obesity and periodontitis were found more consistently for visceral than general adiposity, suggesting that visceral fat accumulation measurement may be more strongly associated with periodontitis more than BMI. ${ }^{29}$ So we suggest for further study including waist hip ratio as a comparing method for BMI measurement.

\section{Conclusion}

This study showed a significant correlation between BMI and periodontitis in Indonesian adults. Therefore, BMI evaluation can be used as a factor for assessing the risk of periodontitis.

\section{Data availability}

Underlying data

Harvard Dataverse: Raw Data of effect of obesity on risk and severity of periodontitis. https://doi.org/10.7910/DVN/ MBVN3O. ${ }^{33}$

This project contains the following extended data:

- Data_Subject_ObesityResearch.tab (raw per subject data).

Data are available under the terms of the Creative Commons Zero "No rights reserved" data waiver (CC0 1.0 Public domain dedication).

\section{Consent}

Written informed consent for publication of the patient details was obtained from the patients.

\section{Author contributions}

CM: Data Curation, Investigation, Visualization, Writing-Original Draft Preparation, Writing-Review \& Editing; EIA: Conceptualization, Recourses, Supervision, Validation, Writing-Review \& Editing; SLM: Methodology, Recourses, Supervision; LSK: Formal Analysis, Supervision, Validation; CP: Formal Analysis, Supervision; NS: Data Curation, Formal Analysis.

\section{Acknowledgments}

The authors wish to acknowledge the Universitas Indonesia for funding the work.

1. Reynolds M: Modifiable Risk Factors in Periodontitis: At the Intersection of Aging and Disease. Periodontol 2000. 2014; 64 7-19.

PubMed Abstract | Publisher Full Text

2. Caton J, Quinones C: Etiology of Periodontal Disease. Curr Opin Dent. 1991; 1: 17-28. PubMed Abstract

3. da Silva MK, de Carvalho ACG, Alves EHP, et al.: Genetic Factors and the Risk of Periodontitis Development: Findings from a Systematic Review Composed of 13 Studies of Meta-Analysis with 71,531 Participants. Int J Dent. 2017; 2017 1914073.

PubMed Abstract | Publisher Full Text | Free Full Text

4. Pan W, Wang Q, Chen Q: The Cytokine Network Involved in the Host Immune Response to Periodontitis. Int J Oral Sci. 2019; 11: 30.

PubMed Abstract | Publisher Full Text | Free Full Text
5. Eaimworawuthikul S, Thiennimitr $\mathrm{P}$, Chattipakorn N, et al.: DietInduced Obesity, Gut Microbiota and Bone, Including Alveolar Bone Loss. Arch Oral Biol. 2017; 78: 65-81.

PubMed Abstract | Publisher Full Text

6. WHO: Obesity and Overweight. In:Newsroom fact sheet. 2018.

7. National Health and Nutrition Examination Survey: 2017. Accessed 2nd July 2019.

Reference Source

8. Kemenkes: Riskesdas 2018. 2018. Accessed 20 Dec, 2020. Reference Source

9. Yajnik C, Yudkin J: Appropriate Body-Mass Index for Asian Populations and Its Implications for Policy and Intervention Strategies. The Lancet. 2004; 363: 157-63. PubMed Abstract | Publisher Full Text

10. Inoue S, Zimmet P, Caterson I, et al.: The Asia-Pacific Perspective: Redifining Obesity and Its Treatment. In: Int Assoc Study Obesity. 2000: 50 pages. 
11. Ana P, Dimitrije $M$, Ivan $M$, et al.: The Association between Periodontal Disease and Obesity among Middle-Aged Adults Periodontitis and Obesity. J Metabolic Synd. 2016; 5(3): 208. Publisher Full Text

12. Suvan JE, Petrie A, Nibali L, et al.: Association between Overweight/Obesity and Increased Risk of Periodontitis. J Clin Periodontol. 2015; 42(8): 733-9. PubMed Abstract | Publisher Full Text

13. Khan S, Barrington $G$, Bettiol S, et al.: Is Overweight/Obesity a Risk Factor for Periodontitis in Young Adults and Adolescents?: A Systematic Review. Obes Rev. 2018; 19(6): 852-83. PubMed Abstract | Publisher Full Text

14. Kim EJ, Jin BH, Bae KH: Periodontitis and Obesity: A Study of the Fourth Korean National Health and Nutrition Examination Survey.J Periodontol. 2011; 82(4): 533-42. PubMed Abstract | Publisher Full Text

15. Prpić J, Kuiš D, Glažar I, et al.: Association of Obesity with Periodontitis, Tooth Loss and Oral Hygiene in Non-Smoking Adults. Cent Eur J Public Health. 2013; 21(4): 196-201. PubMed Abstract | Publisher Full Text

16. Gómez-Hernández A, Beneit N, Díaz-Castroverde S, et al.: Differential Role of Adipose Tissues in Obesity and Related Metabolic and Vascular Complications. Int J Endocrinol. 2016; 2016: 1-15.

PubMed Abstract | Publisher Full Text | Free Full Text

17. Martinez-Herrera M, Silvestre-Rangil J, Silvestre FJ: Association between Obesity and Periodontal Disease. A Systematic Review of Epidemiological Studies and Controlled Clinical Trials. Med Oral Patol Oral Cir Bucal. 2017; 22(6): e708-e15. PubMed Abstract | Publisher Full Text | Free Full Text

18. Suvan J, Petrie A, Moles DR, et al.: Body Mass Index as a Predictive Factor of Periodontal Therapy Outcomes. J Dent Res. 2014; 93(1): 49-54

PubMed Abstract | Publisher Full Text | Free Full Text

19. Greene JG, Vermillion JR: The Simplified Oral Hygiene Index. J Am Dent Assoc. 1964; 68(1): 7-13.

PubMed Abstract | Publisher Full Text

20. Loe H: The Gingival Index, the Plaque Index and the Retention Index Systems. J Periodontol. 1967; 38(6): 610-6. PubMed Abstract | Publisher Full Text

21. Saxer U, Mühlemann H: Motivation and Education. Schweiz Monatsschr Zahnheilkd. 1975; 85(9): 905-19. PubMed Abstract

22. Caton JG, Armitage G, Berglundh T, et al.: A New Classification Scheme for Periodontal and Peri-Implant Diseases and Conditions - Introduction and Key Changes from the 1999
Classification. J Clin Periodontol. 2018; 45: S1-S8. PubMed Abstract | Publisher Full Text

23. Gulati N, Masamatti S, Chopra P: Association between Obesity and Its Determinants with Chronic Periodontitis: A Cross-Sectional Study. J Indian Soc Periodontol. 2020; 24(2): 167-72. PubMed Abstract | Publisher Full Text | Free Full Text

24. Dhaifullah E, Al-Maweri S, Koppolu P, et al.: Body Mass Index and Periodontal Health Status among Young Saudi Adults: A CrossSectional Study. Ann Saudi Med. 2019; 39(6): 433-40. PubMed Abstract | Publisher Full Text | Free Full Text

25. Lim JU, Lee JH, Kim JS, et al:: Comparison of World Health Organization and Asia-Pacific Body Mass Index Classifications in Copd Patients. Int J Chron Obstruct Pulmon Dis. 2017; 12: 2465-75.

PubMed Abstract | Publisher Full Text | Free Full Text

26. Bhardwaj VK, Sharma D, Jhingta P, et al.: Assessment of Relationship between Body Mass Index and Periodontal Status among State Government Employees in Shimla, Himachal Pradesh. J Int Soc Prev Community Dent. 2013; 3(2): 77-80.

PubMed Abstract | Publisher Full Text | Free Full Text

27. Zimmermann H, Hagenfeld D, Diercke K, et al.: Pocket Depth and Bleeding on Probing and Their Associations with Dental, Lifestyle, Socioeconomic and Blood Variables: A Cross-Sectional, Multicenter Feasibility Study of the German National Cohort. BMC Oral Health. 2015; 15: 7. PubMed Abstract | Publisher Full Text | Free Full Text

28. Song IS, Han K, Ryu J, et al.: Association between Underweight and Tooth Loss among Korean Adults. Sci Rep. 2017; 7: 41524

PubMed Abstract | Publisher Full Text | Free Full Text

29. Keller A, Rohde JF, Raymond K, et al: : Association between Periodontal Disease and Overweight and Obesity: A Systematic Review.J Periodontol. 2015; 86(6): 766-76. PubMed Abstract | Publisher Full Text

30. Suvan JE, Finer N, D'Aiuto F: Periodontal Complications with Obesity. Periodontol 2000. 2018; 78(1): 98-128. PubMed Abstract | Publisher Full Text

31. Susanto $H$, Nesse W, Kertia N, et al.: Prevalence and Severity of Periodontitis in Indonesian Patients with Rheumatoid Arthritis. J Periodontol. 2013; 84(8): 1067-74. PubMed Abstract | Publisher Full Text

32. Al Habashneh R, Azar W, Shaweesh A, et al.: The Relationship between Body Mass Index and Periodontitis among Postmenopausal Women. Obes Res Clin Pract. 2016; 10(1): 15-23. PubMed Abstract | Publisher Full Text 


\section{Open Peer Review}

\section{Current Peer Review Status:}

\section{Version 1}

Reviewer Report 15 September 2021

https://doi.org/10.5256/f1000research.57246.r90954

(c) 2021 Zafar M. This is an open access peer review report distributed under the terms of the Creative Commons Attribution License, which permits unrestricted use, distribution, and reproduction in any medium, provided the original work is properly cited.

\section{Muhammad Sohail Zafar}

Department of Restorative Dentistry, College of Dentistry, Taibah University, Medina, Saudi Arabia

The title of the study is clear and concise.

The abstract of the study is adequately written, mentioning the key aspects of the paper.

The introduction is clearly written with relevant and latest citations. However, the authors should mention the names of proinflammatory cytokines before abbreviating them (Page 3, second paragraph). Furthermore, the introduction should be expanded a bit as it seems to be brief, especially the first and second paragraphs.

In the methods section, the authors should mention the STROBE checklist as it is an observational study.

In the methods section, the authors should separate the diagnostic criteria of periodontal disease and obesity by giving them separate sub-headings.

The authors should also mention the null hypothesis of this study.

The authors should carefully check the use of abbreviations in the main text, tables, and figures.

Is the work clearly and accurately presented and does it cite the current literature? Yes

Is the study design appropriate and is the work technically sound? Yes

Are sufficient details of methods and analysis provided to allow replication by others? Yes 


\section{If applicable, is the statistical analysis and its interpretation appropriate? Yes}

Are all the source data underlying the results available to ensure full reproducibility? Yes

Are the conclusions drawn adequately supported by the results?

Yes

Competing Interests: No competing interests were disclosed.

Reviewer Expertise: Dentistry

I confirm that I have read this submission and believe that I have an appropriate level of expertise to confirm that it is of an acceptable scientific standard, however I have significant reservations, as outlined above.

Author Response 29 Dec 2021

Elza Ibrahim Auerkari, Faculty of Dentistry, Universitas Indonesia, Jakarta, Indonesia

Dear Sir, thank you so much for the constructive suggestion in our articles. Hereby we revised the article accordingly. The suggested changes and extensions have been implemented in the introduction, paragraphs 1 and 2, of the revised paper. The strobe checklist has been added in the methods section. also the separate the diagnostic criteria between periodontal disease and obesity by giving them separate sub-headings. The null hypothesis of this study has been added to the methods section and the use of abbreviations has been checked and missing ones added.

Competing Interests: There's no competing interests to disclose

Reviewer Report 13 August 2021

https://doi.org/10.5256/f1000research.57246.r90953

(C) 2021 Reni Yuslianti E. This is an open access peer review report distributed under the terms of the Creative Commons Attribution License, which permits unrestricted use, distribution, and reproduction in any medium, provided the original work is properly cited.

\section{Euis Reni Yuslianti}

Department of Oral Biology, Faculty of Dentistry, Jenderal Achmad Yani University, Cimahi, Indonesia

I think this paper excellent and is an important addition to the literature.

Please provide more depth exploring in the discussion, first paragraph - as noted before about 
the correlation between socio-demographic data, oral hygiene and continuous data of body mass index including alcohol, DM, and plaque index.

Please provide more literature and a deeper discussion about how obesity can effect on risk and severity of periodontitis.

Linking to the results, please include more detail about the correlation between BMI, obesity, and metabolic syndrome to severity of periodontitis.

Please add more depth exploring in the discussion related to adipokines that are secreted from fat cells (adipocytes) in obesity which has an important role in regulating metabolic and oxidative stress to periodontitis.

Is the work clearly and accurately presented and does it cite the current literature? Yes

Is the study design appropriate and is the work technically sound?

Yes

Are sufficient details of methods and analysis provided to allow replication by others? Yes

If applicable, is the statistical analysis and its interpretation appropriate? Yes

Are all the source data underlying the results available to ensure full reproducibility? Yes

Are the conclusions drawn adequately supported by the results?

Yes

Competing Interests: No competing interests were disclosed.

Reviewer Expertise: Bochemistry and Biomolecular, Oral Biology

I confirm that I have read this submission and believe that I have an appropriate level of expertise to confirm that it is of an acceptable scientific standard.

Author Response 29 Dec 2021

Elza Ibrahim Auerkari, Faculty of Dentistry, Universitas Indonesia, Jakarta, Indonesia

Thank you so much for your kind suggestions for our article.

Regarding your comment we completed as follows: the aspects of discussion in the first paragraph, have been addressed in the revised paper. More literature and a deeper discussion about how obesity can effect the severity of periodontitis also have been added 
to the discussion and references of the revised paper. More detail about the correlation between BMI, obesity, metabolic syndrome to the severity of periodontitis, and discussion about adipokines role in regulating metabolic and oxidative stress to periodontitis have been added to the discussion of the revised paper.

Competing Interests: There is no competing interest to disclose

The benefits of publishing with F1000Research:

- Your article is published within days, with no editorial bias

- You can publish traditional articles, null/negative results, case reports, data notes and more

- The peer review process is transparent and collaborative

- Your article is indexed in PubMed after passing peer review

- Dedicated customer support at every stage

For pre-submission enquiries, contact research@f1000.com 